\title{
Islamic Rural Bank Performance Model in Indonesia
}

\author{
Soleh$^{1}$, Juliansyah Noor ${ }^{2 *}$ \\ 1,2Department of Management STIE La Tansa Mashiro, Indonesia \\ ${ }^{*}$ Corresponding Author: profjul.noor@gmail.com
}

\begin{abstract}
The study aims to confirm research model the research model to specify how corporate culture mediates the influence of leadership skills on Islamic rural bank performance (iRBP). A special questionnaire designed for leaders, employees and customers was used to confirm the proposed model. Furthermore, the data set was composed of perceptions from 264 iRBP leaders, 463 customers, and 327 employees from the iRBP community in Indonesia. Also, structural equation modeling was used for data analysis. Although the results indicated that leadership skills have no significant direct influence on iRBP, it significantly influences iRBP through corporate culture. Therefore, this study examined how leadership skills improve iRBP, although it specifically focused on the banking industry. In addition, it still redounds to the literature by indicating the significance of corporate culture.
\end{abstract}

Keywords: Islamic rural bank; Leadership skills; Corporate culture; Islamic rural bank performance

\section{INTRODUCTION}

Over the last decade, an increase in the cost of funds for Islamic Rural Banks (Soleh \& Sule, 2020), as well as the complexity and diversity of its products, has made this bank to be increasingly specialized (Wulandari, Kassim, Sulung, Iwani, \& Putra, 2016). Therefore, the leadership has a dual role in the business by providing literacy services to customers to properly use the products (Wulandari \& Kassim, 2016; Darus et al., 2017). Furthermore, they ensure their business runs smoothly to achieve its goals. As leaders, directors face various challenges due to changes in the business environment from regulatory terms, especially now that consumers have realized their rights and needs. To effectively deal with this situation, the board of directors needs to obtain training and education to serve them with the soft skills and hard skills necessary to perform the business and increase their cognition (Schaarschmidt \& Walsh, 2018).

Meanwhile, it is well documented that there are several leadership skills (LSs) that leaders need to possess and effectively apply (Jambunathan, Jayaraman, Jayaraman, \& Jayaraman, 2019). In specific, creative and skilled leadership are two essential experts that can increase total bank revenue, profit, welfare, and customer performance (Husti \& Mahyarni, 2019). Furthermore, there is an opinion that effective LSs are contextual and that successful leaders meet their corporate culture and improve their LSs (Warrick, 2017). 
Meanwhile, corporate culture (CC) is linked with a diversity of severe impacts at the person, group, and company levels. This culture can positively affect human capital and corporate performance. Therefore, bank leaders work more effectively when they understand their corporate culture (Bassem \& Adel, 2018).

Corporate culture (CC) includes all the beliefs, values, and ways of doing things, which explain all organizational activities. CC has the most influence on employees, and previous studies have indicated that employees' responses to their work environment and motivation are highly dependent on their belief in their leaders (Bassem \& Adel, 2018). According to Shahzad, Xiu, and Shahbaz (2017), by promoting a friendly and inclusive culture for a subordinate, leaders can successfully get them to carry out organizational goals. Therefore, the leaders play an essential role in supporting employees to understand their job goals, promoting teamwork and a sense of belonging, and improving the company performance (Robijn, Euwema, Schaufeli, \& Deprez, 2020). Employees have a more significant chance of being protected from a poor work environment, while there are less viable options in Islamic Rural Banks. The resource-based theory emphasizes that it brings more competitive advantages to the company by building a more dynamic ability to convert the resources into results (Fainshmidt, Wenger, Pezeshkan, \& Mallon, 2019).

Therefore, it is believed that in the Islamic banking business, LSs play an essential role in providing a work culture where all operational and non-operational employees have a significant opportunity to be encouraged and fully involved in fulfilling customer hopefulness, therefore impacting business goal achievement. Consequently, this study has three contributions: firstly, a new theoretical model was expanded to enrich the existing literature in the study of organizational behavior, focusing on Islamic rural banks. Secondly, the hypothesis was empirically analyzed through data collected by the Banks. Thirdly, in practical terms, we are convinced that the findings of this study reflected the key role of Islamic rural bank culture in today's competitive markets. In particular, since "corporate culture" is a new theory in rural bank management, this study proposes developing a theoretical model to set whether CC mediate LSs influence the Islamic rural bank performance. After a literature review, we described the methods employed to collect analytics data. Subsequently, the results were presented and discussed. Conclusions and suggestions for practical implications were particular to contribute to Bank leaders increasing bank performance through a more inclusive culture.

\section{HYPOTHESIS DEVELOPMENT}

The relationship between LSs and organizational performance has been confirmed in commercial banks (Subramony, Segers, Chadwick, \& Shyamsunder, 2018). Some authors argued that LSs have a more significant influence on Islamic banking because leaders in these organizations have more diverse responsibilities and work more closely with customers and employees (Galanou \& Farrag, 2015; Nurdin \& Yusuf, 2020). Also, an effective leader creates an open and relaxed environment where employees can express their beneficial ideas due to the increased motivation and organizational innovation (Ugaddan \& Park, 2017). Although various studies use different indicators to show the components of Leadership Skills (LSs) affecting the company performance, there is little literature that examines the effect of this skill on performance. For example, Trinugroho et al. (2018) and Goromonzi (2016) examined LSs' effect and found that it can significantly affect performance through three measures: customer performance, human capital, and financial results. For this study and the development of the conceptual model, the first hypothesis was formulated as follows: 
$H_{1}$ : Leadership skills have a positive effect on the iRBP

Corporate Culture (CC) was first described as a collection of environmental, psychological, social, organizational, and situational factors that influence employee's behavior. This culture includes leader-member communication where information is clearly and effectively provided by managers, therefore promoting creation and innovation within the organization unit. Huang, Li, Meschke, and Guthrie (2015) further suggested that an inclusive culture can positively affect human capital and corporate performance. In separate studies, Guiso, Sapienza, and Zingales (2015) categorized CC into five main dimensions: structure, reward and recognition, consistency, warmth, support, and customer service. Also, Guiso et al. (2015) elaborated on banking services in the UK and found a positive association between culture and customer retention rates. Furthermore, Pawirosumarto, Sarjana, and Gunawan (2017) extended this finding and argued that a warm and positive culture positively influences human capital and performance. Weerts, Vermeulen, and Witjes (2018) suggested that successful leaders tend to create a Corporate Culture (CC) that provides optimal support to employees in achieving individual, team, and, ultimately, organizational goals. Therefore, the hypothesis formulation was as follows.

$\mathrm{H}_{2}$ : Leadership skills have a positive effect on corporate culture.

As mentioned earlier, corporate culture (CC) is considered the third most significant performance booster after work environment, economic situation, and competitiveness (Tseng, 2010). Although its influence on outcomes, such as employee turnover intention, human capital, customer performance, and financial performance, is demonstrated in different business settings (Yadav \& Dixit, 2017), such information on Islamic Rural Bank is rare. Because the leadership is more involved in various aspects of operations in this bank, it can be assumed that $\mathrm{CC}$ will have a more significant influence on the Islamic Rural Bank Performance compared to large commercial banks (Nguyen, Nguyen, \& Sila, 2019). For example, Sholihin et al. (2018) concluded that inclusive CC tends to be associated with higher performance and may reduce employee turnover. Therefore, the hypothesis was formulated as follows.

$\mathrm{H}_{3}$ : Corporate culture has a positive effect on the iRBP.

Studies have shown that corporate culture (CC) can mediate the influence of diverse leadership practices, such as supervision, training, autonomy, and engagement on organizational performance, such as service quality and organizational efficiency (Ogbonna \& Harris, 2000). For example, Famiyeh, Asante-Darko, and Kwarteng (2017) empirically asserted that human resource practices indirectly improve customer performance. Likewise, Yadav and Dixit (2017) explored the influence of leadership skills on team culture. Furthermore, they explored the relationship between team culture and performance on new product development in a new high-tech company project in China. This literature collection also showed that leaders greatly influence CC. Hence it can be assumed that CC has a mediating influence on LSs effect on performance. Therefore, the hypothesis was formulated as follows. iRBP

$H_{4}$ : Corporate culture mediates the relationship between leadership skills and the

\section{METHODS, DATA, AND ANALYSIS}

The model was developed according to the information presented in the previous section (Figure 1). In this model, Leadership skill (LSs), Corporate Culture (CC), and the 
Islamic Rural Bank Performance are conceptualized according to the stated hypothesis. The data were collected from February to March 2020.

$\mathrm{H} 4$

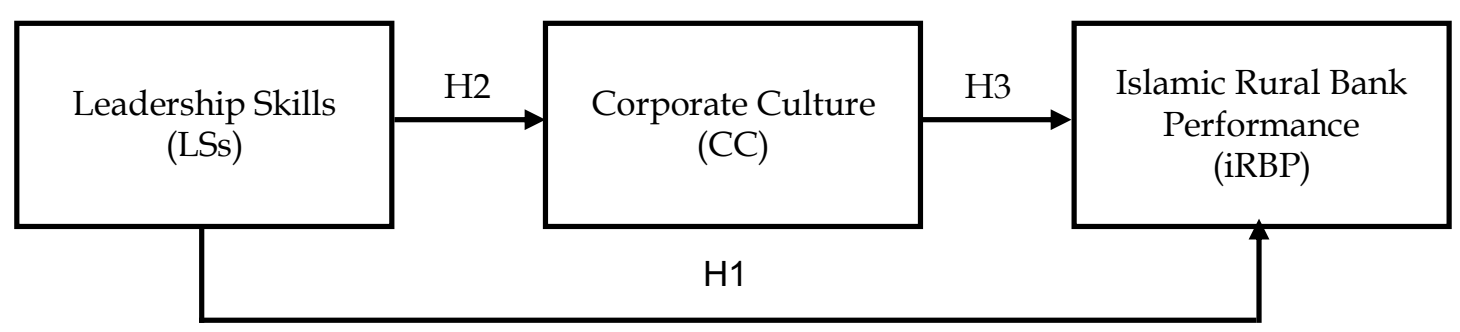

Figure 1. Research Model

In this study, three questionnaires were designed based on previous research (Sholihin et al., 2018; Subramony et al., 2018), one for the leaders, one for the employees, and another for the customers. Furthermore, the leadership questionnaire consisted of three parts: Part A consisted of 20 questions designed to assess leadership skills (LSs) based on a five-point Likert scale. Meanwhile, Part B evaluated financial performance through questions linked to working capital, gross profit, and liquidity. In addition, the last section consisted of questions designed to gather information related to demographics, types of Islamic Rural Bank, and the number of loans given per month that have to be filled out. The questionnaire designed for the employees also consists of three parts: Part A proposed 7 questions related to employees, Part B consisted of 12 question items related to corporate culture (CC). In this study, the CC instrument developed by S.Cameron and E.Quinn. (2011) was applied to measure CC.

The leaders were asked to answer the leadership questionnaires. At least one employee answered the employee questionnaire, and at least two customers answered the customer questionnaire. Also, the questionnaire content validity was confirmed through the expert's opinion. For this objective, experts in Islamic Rural Bank practice were asked about the relativity, clarity, and completeness of the main research questions regarding the objectives. Subsequently, their comments were considered in the development of the final questionnaire. In addition, to ensure the criteria reliability, Cronbach's alpha was calculated based on data collected primarily in pilot studies.

This study population includes all leaders, selected employees currently working at the bank, and a sample of the customers. Due to the large geographical area of Indonesia and a large number of Islamic Rural Bank, sampling was used with a clustering technique to collect data. Furthermore, a sample of 15 provinces was obtained from 34 provinces in Indonesia, and 10 Islamic Rural Banks from each province participated. In total, the returned questionnaires were 264 from leaders, 327 from the employees, and 463 from the customers. This study was conducted between January and May 2020, and more than half of the leaders were males (75.1 percent), and 42.1 percent of participants were between 41 and 50 years old.

Furthermore, most have 11-20 years of work experience (30.5 percent), and the majority of these banks (43.2 percent) provide loans between 11 and 35 clients each month. The employees were also mostly males (52 percent), with the majority (54.1 percent) aged between 21-33 years. Most have work experience of five years or less (44.1 percent), with 42.7 percent having worked three to six years. Furthermore, 58.7 percent of customers were 
females, and 37.4 percent were between 31 and 40 years old. In addition, the majority of customers, 44.2 percent, have completed higher education.

After checking the data distribution normality, structural equation modeling (SEM) was used as the main method for confirming and analyzing the research model. Furthermore, this method was used to test two models, namely measurement and structural. The measurement model determines how the latent variable depends on or is influenced by the observed (manifest) variable.

Also, it describes the measurement attributes (reliability and validity) of the manifest variable. In contrast, SEM examines the existence of a causal relationship between latent variables, direct and indirect effects to explain unexplained variance (Jöreskog, Olsson, \& Wallentin, 2016). Subsequently, the research model was tested employing software of LISREL version 8.7. The characteristic of SEM is its power to give parameter estimates for the unobservable (latent) relationship between variables. Furthermore, SEM performs a path analysis which gives parameter estimates for direct and indirect relationship between latent variables.

\section{4. $\quad$ RESULTS}

We did Harman's factor test to assign the general method bias in the survey report results (Podsakoff, MacKenzie, Lee, \& Podsakoff, 2004). Even though this method was looked a threat of potential to the internal validity of self-reported surveys, the results do not identify a single factor that explains a large proportion of all measurement items. Therefore, to overcome this, the Chi-square test was employed to assign the significant difference between the leaders who responded and those who did not. These test results showed no significant difference between the three groups as follows; gender, age, and educational level. Also, to test the instrument's reliability, Cronbach's alpha was employed to assign the overall reliability of the items from the three questionnaire constructs. The coefficient of all items is above the conservative threshold of 0.70. Moreover, Kaiser (1958) provided criteria for selecting the factors to be tested. The factor testing produced an Eigenvalue $>1$ and a value of absolute for factor loading $>0.50$, therefore ensuring the questionnaire reliability. Besides, the value of Kaiser-Meyer-Olkin (KMO) was employed to assign the suitability of the data for factor analysis, with values $>0.5$ indicating an acceptable verge (Kaiser, 1958). In the leadership questionnaire of Islamic Rural Bank, the lowest Cronbach alpha was related to strategic skills (0.72), and the highest was cognitive skills (0.81).

As shown in Table 1, the reliability test results and factor analysis showed that all dimensions are well designed to measure the appropriate construct. Furthermore, the KMO score provided an excellent opportunity to carry out a factor analysis. Meanwhile, the construct validity was examined via convergent and discrimination tests, which indicated that all mean values of extracted variance (AVE) were more significant than those addressed in the literature (Valmohammadi, 2011), namely 0.5. Regarding discrimination validity, the correlation coefficient between dimensions was smaller than the AVE of each dimension. By the method of Fornell and Larcker (1994), confirmed that all dimensions measure a distinct concept. Therefore, before constellation, a structural model, the measurement model of each construct, was tested and validated employing SEM. The finds showed that all measurement models are appropriate, which means that a structural model can be generated. Figure 2 illustrated the estimates of parameter for the structural model used in this study, and showed the finds of employing SEM to validate and analyze the model. 
Table 1. Results of Factor Analysis

\begin{tabular}{|c|c|c|c|c|c|}
\hline Variables & Items & $\begin{array}{l}\text { Cronbach's } \\
\text { alpha }\end{array}$ & $\begin{array}{l}\text { KMO } \\
\text { value }\end{array}$ & $\begin{array}{c}\text { Factor } \\
\text { loading }\end{array}$ & $\begin{array}{l}\text { AVE } \\
(\%)\end{array}$ \\
\hline \multicolumn{6}{|l|}{ Leadership Skills (LSs) } \\
\hline Cognitive (KO) & 5 & 0.87 & 0.86 & $0.72-0.82$ & 60.98 \\
\hline Interpersonal (IN) & 6 & 0.85 & 0.88 & $0.65-0.83$ & 56.76 \\
\hline Business (BS) & 3 & 0.82 & 0.78 & $0.82-0.91$ & 74.01 \\
\hline Strategic (ST) & 4 & 0.76 & 0.75 & $0.62-0.84$ & 61.74 \\
\hline \multicolumn{6}{|l|}{ Corporate Culture (CC) } \\
\hline Customer Value (NN) & 3 & 0.71 & 0.61 & $0.72-0.92$ & 65.09 \\
\hline Human Resource Value (NS) & 6 & 0.87 & 0.84 & $0.70-0.88$ & 63.36 \\
\hline Performance Standard (SK) & 4 & 0.83 & 0.75 & $0.76-0.88$ & 64.83 \\
\hline Accountability (AK) & 4 & 0.73 & 0.72 & $0.71-0.82$ & 58.74 \\
\hline \multicolumn{6}{|c|}{ Islamic Rural Bank Performance (iRBP) } \\
\hline Human capital (MM) & 5 & 0.79 & 0.76 & $0.65-0.84$ & 56.82 \\
\hline Customer capital (MN) & 5 & 0.84 & 0.75 & $0.62-0.85$ & 64.44 \\
\hline $\begin{array}{l}\text { Financial performance (KR) } \\
\text { - Income/month } \\
\text { - Profits/month } \\
\text { - Liquidity }\end{array}$ & 3 & 0.67 & 0.56 & $0.40-0.91$ & 59.57 \\
\hline
\end{tabular}

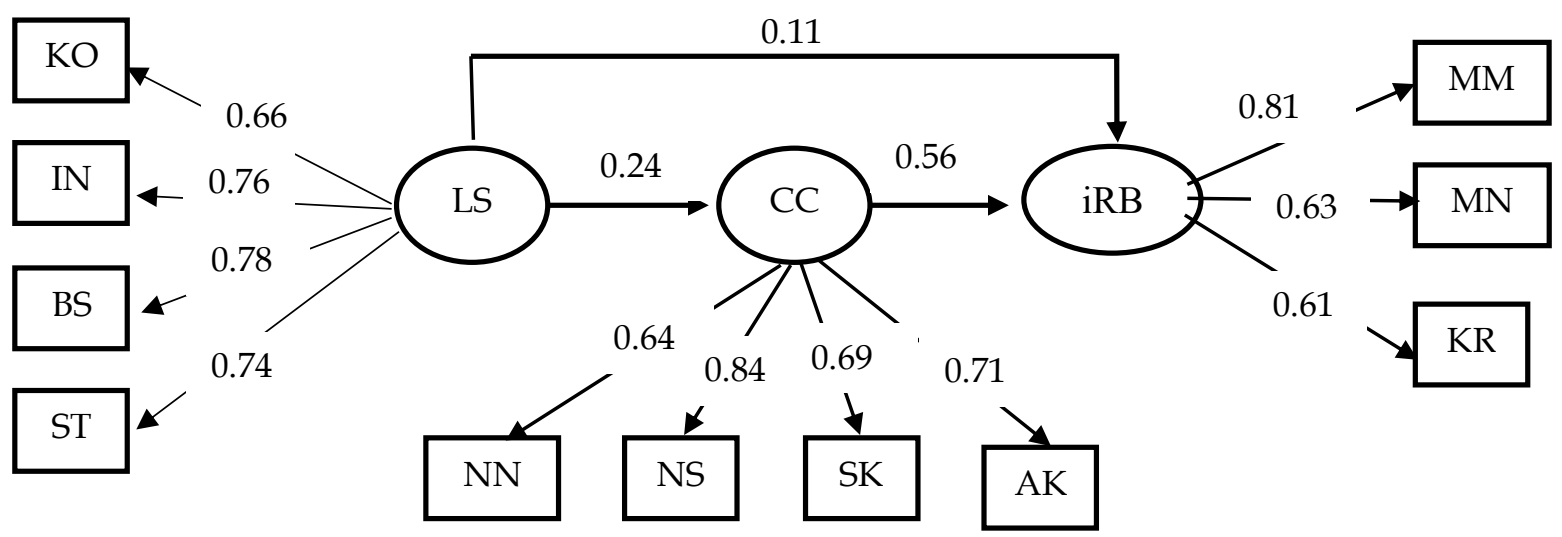

Figure 2. Structure Model

The suitability of an empirical model shows how good it fits into an observation series. The suitability index summarizes the differences between observed and anticipated values. Meanwhile, according to empirical models, absolute suitability indicators, incremental fit indicators, and goodness-of-fit index (GFI) are informed for overall fit validation. These results are shown in Table 2.

The absolute suitability values of the indicator are the Chi-square/degrees value of freedom (df) was 2.6, the GFI was 0.82 , the root mean square residual (RMR) was 0.03 , and the root mean square error of approximation (RMSEA) was 0.07. Most of the literature informed a fit index within appropriate ranges (Carmines \& McIver, 1981). Furthermore, the incremental fit indicator scores are the model-adjusted GFI was 0.85 , the normed fit index (NFI) was 0.93, the comparative fit index was 0.95, and the additional fit index was 0.95. Most of these values meet the levels considered recommended in the literature. Assuming GFI, the parsimonious NFI (PNFI) was 0.76, and the parsimonious GFI (PGFI) 
was 0.65 , both of which are greater than the verge of 0.5 recommended by the prior reference statistics (Hair et al., 2018).

Table 2. Measurement of model fit

\begin{tabular}{lccl}
\hline Fit Indicator & \multicolumn{1}{c}{ Fit criteria } & Validation Value & Results \\
\hline$X^{2} / \mathrm{df}$ & $<3$ & 2.72 & Fit \\
GFI & $>0.90$ & 0.89 & Moderate \\
RMR & $<0.05$ & 0.03 & Fit \\
RMSEA & $<0.05-0.08$ & 0.07 & Fit \\
AGFI & $>0.90$ & 0.85 & Moderate \\
NFI & $>0.90$ & 0.93 & Fit \\
CFI & $>0.90$ & 0.95 & Fit \\
IFI & $>0.90$ & 0.95 & Fit \\
PNFI & $>0.5$ & 0.76 & Fit \\
PGFI & $>0.5$ & 0.65 & Fit \\
\hline
\end{tabular}

Source: Data processing results of Lisrel 8.7 (2020)

Table 3 described the finds of the causal relationship analysis among the three main constructs. As can be seen, LSs have no direct effect on the performance $(t=1.87)$. Conversely, CC has a direct effect on the Islamic Rural Bank Performance $(t=5.65, \beta=0.56)$. These results suggested that LSs promote CC, which in turn improves performance. These findings provided support for the relationship between LSs and CC (H2) as well as the relationship between CC and Islamic Rural Bank performance (H3), but do not provide support for a direct relationship between LSs and performance (H1).

Finally, the effect of total LSs on CC and Islamic Rural Bank performance was examined using path analysis. As shown in Table 4, as an exogenous variable, LSs influence on Bank performance increased significantly through the indirect effect, while the influence is very low and insignificant through the direct effect, which is in line with H1.

As mentioned earlier, this study used two different approaches to examine the effects of LSs on Islamic Bank performance either directly or indirectly. The results showed that LSs significantly and positively contribute to CC. Furthermore, although CC has a positive effect on iRBP, LSs do not because its direct effect on iRBP is 0.11 . The indirect effect of LSs on performance through CC increased to 0.13 after considering the effect of $\mathrm{CC}$ mediation. Consequently, the results showed that there is LSs influence on the Islamic Rural Bank Performance through CC mediation. Therefore these results support H4.

Table 3. Results of SEM Hypothesis Test

\begin{tabular}{llcrcc}
\hline Path & & \multicolumn{2}{c}{$\begin{array}{l}\text { Regression } \\
\text { Standards }(\boldsymbol{\beta})\end{array}$} & Hypothesis & T Value \\
\hline LSs $\rightarrow$ Islamic & Rural & Bank & 0.11 & H1 & 1.87 \\
$\begin{array}{l}\text { Performance } \\
\text { LSs } \rightarrow \text { CC }\end{array}$ & & & 0.24 & H2 & 4.85 \\
$\begin{array}{l}\text { CC } \rightarrow \text { Islamic } \\
\text { Performance }\end{array}$ & Rural & Bank & 0.56 & H3 & 5.65 \\
\hline
\end{tabular}

Source: Results of data processing $\rho<0,05$, Lisrel 8.7 (2020) 


\section{DISCUSSION.}

One of the most critical challenges for bankers is advancing their business objectives while providing appropriate services to their customers. Like medium and large banks, bank managers need several LSs, which are essential to running a successful banking business in today's competitive market. Furthermore, these skills create a positive CC where all technical and non-technical employees can act efficiently, leading to the desired results. Because the literature contains few studies examining how LSs improves the bank's performance, the four hypotheses were proposed based on the reviewed literature to investigate this relationship further.

Table 4. Path Analysis Results

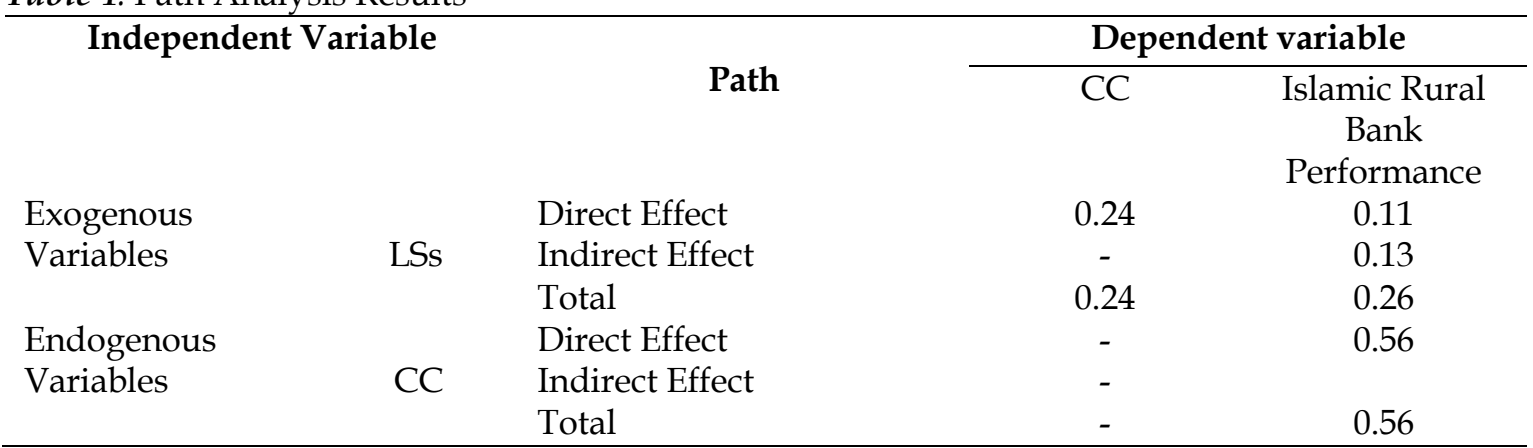

Source: Results of data processing, $\rho<0.05$, Lisrel 8.7 (2020)

The finds of this study indicated that the influence of LSs on iRBP is not statistically significant (H1), which means that these skills affect the bank's performance through indirect paths (Goromonzi, 2016). Although the empirical data does not show that LSs directly affect performance, it is evident that a qualified leader needs to learn and apply these skills. This is because effectively building and maintaining strong customer relationships and managing financial flows is essential to ensure consistent long-term income. Therefore, considering that most Bank leaders in Indonesia graduated from Islamic economics and business schools, additional training to acquire and hone these skills is highly recommended.

$\mathrm{H}_{2}$ is proven. This showed that LSs increased CC on Islamic Rural Bank Performance. An efficient leader will try to structure a business and define all the employee's job descriptions according to their abilities. Such an approach fosters them to be proactive, thereby improving performance. This basis was noted by Sharma, Kong, and Kingshott (2016) that the clarity of overall objectives, well-assigned employee responsibilities, and a clear grasping of the extent to which employees can combine their innovations are the most significant factors involved in CC development.

The results of this study showed that employees will lose interest in working with the board of directors when they are not included in the decision-making process, which can cause businesses to lose ideas. Furthermore, when the employees are not involved in this process, they may mentally isolate themselves, which can trigger emotional disconnection. To avoid this, the board needs to adopt interactive and collaborative management methods to improve CC.

The influence of CC on Islamic Rural Bank Performance has been studied in many works of literature. For example, Tseng (2010) found a positive influence between CC and the performance of small banks, and the higher the corporate culture score achieved by a company, the higher its performance. The finds of this study indicated that CC has a 
positive and significant effect on iRBP. Therefore, $\mathrm{H} 3$ is supported. This finding is by Sholihin et al. (2018) and Yadav and Dixit (2017), which stated that workplace culture significantly influenced employee behavior and business performance. With this relationship, a strong CC can also improve service quality and the level of innovation and risk-taking, which can increase customer profits and loyalty.

CC's findings mediate the influence of LSs on iRBP, which supports H4. These results showed that LSs implementation in the context of Islamic Rural Bank could indirectly improve company performance by increasing CC. Therefore, all LSs attributes can be used to improve the performance from time to time significantly. This is well supported by (Ogbonna \& Harris, 2000; Famiyeh et al., 2017). Although this study only investigated the one-way effect of these variables, the relationship between CC and performance can be considered a two-way interaction like the model recommended by Yadav and Dixit (2017). Furthermore, considering the context of Islamic Rural Bank, it appears that in practice as a small bank, the community, both technical and non-technical communicates closely with each other. Therefore, directors should strive to build a constructive culture in which all staff can work professionally and efficiently.

\section{CONCLUSIONS}

Islamic Rural Bank plays a major role in improving people's quality of life by providing financial products and services, and it cannot be denied that successful businesses provide these services more effectively. Accordingly, four hypotheses were developed and tested based on a literature review to provide a broader insight into how a board of directors can build a more successful business. This study showed that efforts to improve all LSs aspects could increase iRBP through the positive influence of CC mediation. Meanwhile, successful leaders understand the work environment and improve their skills to create a pleasant culture where customer needs can be effectively met, and human resources can be optimized. Ultimately, the result of this approach will be greater benefits and long-term stability for Islamic Rural Bank.

Furthermore, getting the LSs needed not only to improve the iRBP but also the quality of banking services. Since most managers are trained as professional bankers, it is very important to obtain technical LSs to improve performance. These findings can generalize Rural banks in different cultures, which needs to be evaluated in other studies. In other words, the specification of culture in various contexts has to be considered to obtain a better generalizability estimate of the results.

Although the findings are new, there are several limitations. The first is the questionnaire results, consisting of subjective responses from directors, managers, employees, and customers. The second limitation relates to uncertainty about the precision of answers and the necessary for indirect calculations on the Islamic Rural Bank Performances. Therefore, further research can investigate mediation from other dimensions on the relationship between LSs and Islamic Rural Banks. Moreover, it is necessary to examine how iRBP can be improved.

\section{REFERENCES}

Bassem, E. M., \& Adel, S. (2018). How organizational culture and leadership affect employees performance genders. International Journal of Organizational Analysis, 26(4), 630-651. https:// doi.org/10.1108/ijoa-04-2017-1151

Carmines, E. G., \& McIver, J. P. (1981). Analyzing models with unobserved variables: 
analysis of covariance structuresNo Title. SocialMeasurement: Current Issues, 65-115.

Darus, F., Ahmad Shukri, N. H., Yusoff, H., Ramli, A., Mohamed Zain, M., \& Abu Bakar, N. A. (2017). Empowering social responsibility of Islamic organizations through Waqf. Research in International Business and Finance, 42, 959-965. https://doi.org/10.1016/j.ribaf.2017.07.030

Fainshmidt, S., Wenger, L., Pezeshkan, A., \& Mallon, M. R. (2019). When do Dynamic Capabilities Lead to Competitive Advantage? The Importance of Strategic Fit. Journal of Management Studies, 56(4), 758-787. https:// doi.org/10.1111/joms.12415

Famiyeh, S., Asante-Darko, D., \& Kwarteng, A. (2017). Service quality, customer satisfaction, and loyalty in the banking sector: the moderating role of organizational culture. International Journal of Quality \& Reliability Management, 35(8), 1546-1567. https://doi.org/https://doi.org/10.1108/IJQRM-01-2017-0008

Fornell, C., \& Larcker, D. (1994). Structural equation models with unobservable variables and measurement error: Algebra and statistics. Journal of marketing research. Advances Methods of Marketing Research, 18(3), 382-388.

Galanou, A., \& Farrag, D. A. (2015). Towards the distinctive Islamic mode of leadership in business. Journal of Management Development, 34(8), 882-900. https://doi.org/https://doi.org/10.1108/JMD-09-2014-0096

Goromonzi, W. O. (2016). Organizational Culture , Strategy Implementation and Commercial Bank Performance in Zimbabwe, 6(2), 307-316.

Guiso, L., Sapienza, P., \& Zingales, L. (2015). The value of corporate culture. Journal of Financial Economics, 117(1), 60-76. https:/ / doi.org/10.1016/j.jfineco.2014.05.010

Hair, F. H., Black, W. C., Babin, B. J., Anderson, R. E., Black, W. C., \& Anderson, R. E. (2018). Multivariate Data Analysis (7th Editio). Hampshire, UK Cengage Learning. https:/ / doi.org/10.1002/9781119409137.ch4

Huang, M., Li, P., Meschke, F., \& Guthrie, J. P. (2015). Family firms, employee satisfaction, and corporate performance. Journal of Corporate Finance, 34, 108-127. https://doi.org/10.1016/j.jcorpfin.2015.08.002

Husti, I., \& Mahyarni, M. (2019). Islamic Leadership, Innovation, Competitive Advantages, and Performance of SMEs in Indonesia. East Asia, 36(4), 369-383. https:/ / doi.org/10.1007/s12140-019-09325-7

Jambunathan, S., Jayaraman, J. D., Jayaraman, K., \& Jayaraman, A. (2019). Effect of PeerLed Leadership Workshops on Leadership Skills Among Middle School Students in India. Journal of Research in Childhood Education, 33(3), 399-413. https://doi.org/10.1080/02568543.2019.1608336

Jöreskog, K. G., Olsson, U. H., \& Wallentin, F. Y. (2016). Multivariate Analysis with LISREL. (P. Bickel, P. Diggle, S. E. Fienberg, U. Gather, \& S. Zeger, Eds.), Springer International Publishing (Springer S, Vol. 34). Switzerland: Springer. https:/ / doi.org/10.1007/9783-319-33153-9

Kaiser, H. F. (1958). The varimax criterion for analytic rotation in factor analysis. Psychometrika, 23(3), 187-200. https:/ / doi.org/10.1007/BF02289233

Nguyen, D. D., Nguyen, L., \& Sila, V. (2019). Does Corporate Culture Affect Bank Risk- 
Taking? Evidence from Loan-Level Data. British Journal of Management, 30(1), 106133. https:// doi.org/10.1111/1467-8551.12300

Nurdin, \& Yusuf, K. (2020). Knowledge management lifecycle in Islamic bank: the case of syariah banks in Indonesia. International Journal of Knowledge Management Studies, 11(1). https://doi.org/https:/ / doi.org/10.1504/IJKMS.2020.105073

Ogbonna, E., \& Harris, L. C. (2000). Leadership style, organizational culture and performance: Empirical evidence from UK companies. International Journal of Human Resource Management, 11(4), 766-788. https:/ / doi.org/10.1080/09585190050075114

Pawirosumarto, S., Sarjana, P. K., \& Gunawan, R. (2017). The effect of work environment, leadership style, and organizational culture towards job satisfaction and its implication towards employee performance in Parador hotels and resorts, Indonesia. International Journal of Law and Management, 59(6), 1337-1358. https://doi.org/10.1108/IJLMA-10-2016-0085

Podsakoff, P. M., MacKenzie, S. B., Lee, J. Y., \& Podsakoff, N. P. (2003). Common Method Biases in Behavioral Research: A Critical Review of the Literature and Recommended Remedies. Journal of Applied Psychology, 88(5), 879-903. https://doi.org/10.1037/0021-9010.88.5.879

Robijn, W., Euwema, M. C., Schaufeli, W. B., \& Deprez, J. (2020). Leaders, teams and work engagement: a basic needs perspective. Career Development International, 25(4), 373388. https:// doi.org/10.1108/CDI-06-2019-0150

S.Cameron, K., \& E.Quinn., R. (2011). Diagnosing and changing organizational culture: based on the competing values framework (Third Edit). Reading, UK: Addison-Wesley.

Schaarschmidt, M., \& Walsh, G. (2018). Social media-driven antecedents and consequences of employees' awareness of their impact on corporate reputation. Journal of Business Research, 117(12), 718-726. https:/ / doi.org/10.1016/j.jbusres.2018.11.027

Shahzad, F., Xiu, G. Y., \& Shahbaz, M. (2017). Organizational culture and innovation performance in Pakistan's software industry. Technology in Society, 51, 66-73. https:// doi.org/10.1016/j.techsoc.2017.08.002

Sharma, P., Kong, T. T. C., \& Kingshott, R. P. J. (2016). Internal Service Quality as a Driver of Employee Satisfaction, Commitment and Performance - Exploring the Focal Role of Employee Well-being. Journal of Service Management, 27(5), 773-797. https://doi.org/https://doi.org/10.1108/JOSM-10-2015-0294

Sholihin, M., Zaki, A., \& Maulana, A. O. (2018). Do Islamic rural banks consider Islamic morality in assessing credit applications? Journal of Islamic Accounting and Business Research, 9(4), 498-513. https://doi.org/10.1108/JIABR-01-2018-0015

Soleh, I., \& Sule, E. T. (2020). COMPETITIVE ADVANTAGE MODEL AND ITS IMPLICATION ON THE PERFORMANCE OF ISLAMIC, 19(3), 1-15.

Subramony, M., Segers, J., Chadwick, C., \& Shyamsunder, A. (2018). Leadership development practice bundles and organizational performance: The mediating role of human capital and social capital. Journal of Business Research, 83(September 2017), 120-129. https://doi.org/10.1016/j.jbusres.2017.09.044

Trinugroho, I., Risfandy, T., \& Ariefianto, M. D. (2018). Competition, diversification, and 
bank margins: Evidence from Indonesian Islamic rural banks. Borsa Istanbul Review, 18(4), 349-358. https:/ / doi.org/10.1016/j.bir.2018.07.006

Tseng, S. M. (2010). The correlation between organizational culture and knowledge conversion on corporate performance. Journal of Knowledge Management, 14(2), 269284. https:/ / doi.org/10.1108/13673271011032409

Ugaddan, R. G., \& Park, S. M. (2017). Quality of leadership and public service motivation: A social exchange perspective on employee engagement. International Journal of Public Sector Management, 30(3), 270-285. https://doi.org/https://doi.org/10.1108/IJPSM08-2016-0133

Valmohammadi, C. (2011). The impact of TQM implementation on the organizational performance of Iranian manufacturing SMEs. TQM Journal, 23(5), 496-509. https://doi.org/10.1108/17542731111157608

Warrick, D. D. (2017). What leaders need to know about organizational culture. Business Horizons, 60(3), 395-404. https://doi.org/10.1016/j.bushor.2017.01.011

Weerts, K., Vermeulen, W., \& Witjes, S. (2018). On corporate sustainability integration research: Analysing corporate leaders' experiences and academic learnings from an organisational culture perspective. Journal of Cleaner Production, 203, 1201-1215. https://doi.org/10.1016/j.jclepro.2018.07.173

Wulandari, P., \& Kassim, S. (2016). Issues and challenges in financing the poor: case of Baitul Maal Wa Tamwil in Indonesia. International Journal of Bank Marketing, 34(2), 216-234. https:// doi.org/10.1108/IJBM-01-2015-0007

Wulandari, P., Kassim, S., Sulung, L. A., Iwani, N., \& Putra, S. (2016). Unique aspects of the Islamic microfinance financing process: Experience of Baitul Maal Wa Tamwil in Indonesia. Humanomics, 32(3), 230-247. https:// doi.org/https://doi.org/10.1108/H09-2014-0062

Yadav, N., \& Dixit, S. (2017). A Conceptual Model of Learning Agility and Authentic Leadership Development: Moderating Effects of Learning Goal Orientation and Organizational Culture. Journal of Human Values, 23(1), 40-51. https://doi.org/10.1177/0971685816673487 